\title{
MUSIIKILLISEN MAAILMANKUVAN RAKENNE JA TYYPIT MUSIIKKIKIRJASTONHOITAJILLA
}

Musiikillisen maailmankuvan käsite on vielä uusi ja tutkimuksessa vähän käytetty. Tarkastelen aluksi käsitteen syntyä ja kehitystä etnomusikologian tutkimustraditiossa ja esittelen, miten musiikillinen maailmankuva määrittyy ja tematisoituu tutkimuskohteeksi kognitiivisen psykologian maailmankuvateorian pohjalta. Kuvailen sen jälkeen musiikkikirjastonhoitajiin kohdistuneen haastattelututkimuksen tuloksena syntynyttä musiikillisen maailmankuvan "typologiaa" ja teen lopuksi huomioita musiikillisen maailmankuvan rakenteesta.

\section{Musiikillisen maailmankuvan käsitteen taustaa}

Musiikillisen maailmankuvan käsitteen synnyn taustalla on etnomusikologian piirissä 1970-luvulta lähtien ja etenkin 1980-luvulla virinnyt uusi "kognitiivinen tutkimusparadigma", jossa näkökulma on siirtynyt itse musiikin tutkimisesta musiikilliseen ajatteluun, havaitsemiseen ja ymmärtämiseen. Musiikkikognition tutkimuksessa pyritään saamaan tietoa siitä, miten ihminen mentaalisesti hahmottaa häntä ympäröiviä musiikillisia ilmiöitä (Pekkilä 1988,54). Kognitiivisen musiikkikulttuurin tutkimuksen kohde voi löytyä mistä tahansa musiikkikulttuurin osa-alueesta, tärkeää on kognitiivinen näkökulma, josta asiaa tai ilmiötä tarkastellaan. 
Musiikkikognition käsite sisältää musiikkikulttuurin kaikki kognitiiviset piirteet, myös musiikin tekemisen, säveltämisen, esittämisen ja vastaanottamisen kognitiiviset prosessit. (Moisala 1988, 139-140, 150.)

Kognitiivisesti värittyneiden etnomusikologisten tutkimusten ja musiikillisen maailmankuvan käsitteen taustalla on Alan P. Merriamin esittämä musiikkikulttuurin kolmitasoinen tutkimusmalli. Merriamin mallin mukaan musiikkikulttuuri rakentuu musiikkiin liittyvien käsitteiden (concepts) eli musiikin käsitteellistämisen, musiikkiin liittyvän toiminnan eli musiikkikäyttäytymisen ja sen tuloksena syntyvien musiikkituotteiden eli soivan musiikin väliselle dynamiikalle. Tutkimustasot muodostavat kehän, sillä soiva musiikki muuttaa palautteen kautta edelleen musiikkia koskevia käsityksiä, jolloin koko musiikkikulttuuri on jatkuvassa muutostilassa. (Merriam 1964, 32-35.)

"Kognitiivisessa etnomusikologiassa" kiinnostus kohdistuu Merriamin tutkimusmallin käsitteet-tasoon eli musiikkikäsitteistöön, kuten termi yleensä suomennetaan. Merriamin tutkimusmallissa jää kuitenkin melko epäselväksi, mitä musiikkikäsitteet tarkkaan ottaen ovat. Merriamin määritelmän mukaan musiikin käsitteellistäminen koskettelee ennen kaikkea kysymyksiä siitä, mitä musiikki on tai mitä sen tulisi olla, mistä musiikki on peräisin ja mitkä ovat inhimillisen musikaalisuuden lähteet. Musiikin käsitteellistämisen avulla musiikki integroidaan osaksi yhteisön kokonaistoimintoja, täsmennetään sen merkityksiä ja funktioita. Musiikkikäsitteet muodostavat Merriamin mukaan viitekehyksen, jonka mukaan yhteisö organisoi musiikkinsa, ne ovat sekä musiikillisen äänen että siihen liittyvien asenteiden ja arvojen taustalla. (Merriam 1964, 33, 103.)

Merriamin musiikkikäsitteistö-termin epätarkkuus ei ole aiheuttanut ongelmia silloin kun on tutkittu musiikkiperinnettä homogeenisissa yhteisöissä, joissa esimerkiksi musiikin alkuperää koskevat myyttiset kertomukset vielä elävät ja joilla on yhtenäiset musiikkikäsitykset, kun tavoitteena on ollut eri musiikkikulttuurien vertailu tai kun tutkimusta on tehty Merriamin tutkimusmallin mukaisesti kaikilla kolmella tasolla. Moderni etnomusikologia on kuitenkin yhä enenevässä määrin suuntautunut kaupungistuneissa ja teollistuneissa viestintäyhteiskunnissa ilmenevän musiikkikulttuurin tutkimukseen. Eriytyneen työnjaon yhteiskunnissa ei vallitse yhtenäistä musiikkikäsitteistöä, kulttuurin jäsenet eivät reagoi Merriamin olettamalla tavalla yhtenäisesti kuulemaansa musiikkiin. Merriamin termi ei sovellu tutkimuksen avainkäsitteeksi silloin kun tutkitaan monimutkaisia yhteisöjä tai kun pyritään selvittämään yhden tai useamman henkilön musiikillista ajattelua koko- 
naisuutena. Ei ole järkevää puhua "käsitteistä" silloin kun on kysymys yksilöllisistä elämyksistä, esimerkiksi yksilön tekemistä assosiaatioista akustisten ilmiöiden ja ulkomusiikillisten tapahtumien välillä.

1970-luvun alkupuolella Suomessa virinnyt maailmankuvatutkimus antoi etnomusikologeille virikkeen uuden termin, musiikillisen maailmankuvan, käyttöönottoon 1980-luvun alussa. Maailmankuvatutkimuksesta omaksuttiin termi, mutta maailmankuvatutkimuksen teoriaa ei juuri ole käytetty hyväksi käsitteen sisällön täsmentämiseen. Pikemminkin käsitteen määrittelyä on sävyttänyt Merriamin alkuperäiskäsite ja etnomusikologian tutkimusperinne. Perinteiset etnomusikologiset musiikkikäsitteistön tutkimukset ovat suuntautuneet musiikkiterminologian ja -sanaston sekä musiikin luomista koskevien käsitysten ja sääntöjen selvittämiseen. Tällaisten tutkimusten yhteydessä ovat musiikillisen maailmankuvan käsitettä käyttäneet Heikki Laitinen (1982) ja Vesa Kurkela (1983). Käytettäessä musiikillisen maailmankuvan käsitettä tällaisten tutkimusten yhteydessä on käsitteenmäärittelyssä poikettu jossain määrin siitä, mitä maailmankuvan käsitteellä on tieteessä yleensä tarkoitettu. Musiikkikognition tutkimuksessa onkin syytä erottaa toisistaan perinteinen musiikin luomista koskevien käsitysten ja sääntöjen tutkimus sekä yksilön tai yhteisön musiikillista maailmankuvaa koskeva tutkimus, ne ovat toisistaan eroavia tutkimuskohteita, jotka edellyttävät erilaisia tutkimusmetodeja. ${ }^{1}$ Erkki Pekkilä jakaa Eero Tarastin esittämiä termejä muuntaen musiikkia koskevan puheen ideologiseen ja tekniseen diskurssiin. Ideologinen diskurssi käsittelee Pekkilän mukaan musiikin estetiikkaa, arvoja ja arvostuksia eli musiikillista maailmankuvaa, kun taas tekninen diskurssi on kotoperäistä informaatiota soittamisesta toimintana tai musiikista rakenteellisena ilmiönä. (Pekkilä 1988, 62-64.) On kuitenkin huomattava, että ideologian ja maailmankuvan käsitteillä on oleellisia eroja. Maailmankuvia voidaan tarkastella joko yksilön tai yhteisön tasolla kun taas ideologia on aina useille yksilöille yhteinen henkinen muodoste, johon liittyy vaatimus henkisestä aktiivisuudesta ja välittömästä praktisesta merkityksellisyydestä. Maailmankuva on ideologiaa fundamentaalisempi, syvemmällä olevia tietoisuuden kerroksia ilmentävä käsite. (Manninen 1977, 23-26.) Musiikillinen maailmankuva

1) Soittajan etnoteorian tutkiminen edellyttää samalla myös itse musiikin tutkimista, koska kaikki musiikinteon pohjalla olevat käsitykset eivät ole ilmaistavissa verbaalisesti, vaan osa niistä ilmenee yksinomaan soivassa musiikissa (Pekkilä 1983). Maailmankuva on tutkittavissa pelkästään verbaalisen kommunikaation avulla edellyttäen, että yksilö pystyy tiedostamaan maailmankuvansa piirteitä ja kuvailemaan niitä (Rauste-von Wright 1979, 10, 20). 
on jokaisella yksilöllä ja se voi olla enemmän tai vähemmän tiedostettu, sen sijaan harvojen yksilöiden käsitykset musiikista ovat muodostuneet selkeäksi ja johdonmukaiseksi musiikki-ideologiaksi.

Toinen etnomusikologian tutkimustraditioon liittyvä piirre on, että musiikillisen maailmankuvan käsite ymmärrettiin ja määriteltiin aluksi nimenomaan yksilöllisiin musiikkikäsityksiin viittaavaksi termiksi. Vesa Kurkela $(1986 \mathrm{a}, 15)$ on määritellyt musiikillisen maailmankuvan yhteisön musiikillista ajattelua ohjaavaksi käsitevarastoksi. "Kognitiivinen etnomusikologia" on syntynyt kognitiivisesta antropologiasta saaduista vaikutteista, ja antropologisissa kognitiotutkimuksissa on tieteenalan luonteen mukaisesti yleensä operoitu yhteisön tai kokonaiskulttuurin tasolla (Moisala 1988, 142). Tällöin tutkimuksen kohteena ovat olleet pikemminkin kognitiiviset struktuurit, kognitioiden laatu ja sisältö kuin yksilöiden ajatteluprosessit (emt, 142).

Musiikkikirjastonhoitajien musiikillista maailmankuvaa koskevassa tutkimuksessani (Karttunen 1990) olen hahmotellut musiikillisen maailmankuvan teoreettista viitekehystä kognitiivisen psykologian maailmankuvatutkimuksessa kehitettyä ns. systeemiteoreettista viitekehystä soveltaen. Kyseessä on yksilötason tutkimus, jolloin musiikillisen maailmankuvan käsite ymmärretään eri tavalla kuin yhteisön musiikillista maailmankuvaa tarkastelevissa tutkimuksissa. Kognitiivista psykologiaa ei musiikkikognition tutkimuksessa ole aikaisemmin juuri hyödynnetty, vaikka sitä voidaan hyvin soveltaa myös yksilön musiikillisen ajattelun tutkimuksessa, onhan kognitiivisen psykologian tutkimuskohteena nimenomaan yksilöiden ajatteluprosessit.

\section{Musiikillinen maailmankuva kognitiivisen psykologian maailmankuvateorian viitekehyksessä}

Kognitiivisen psykologian maailmankuvateoriassa maailmankuvalla tarkoitetaan yksilölle hänen kehityksensä myötä rakentuvaa "maailman sisäistä representaatiota", hänen omaa minää ja ulkomaailmaa koskevien käsitysjärjestelmiensä kokonaisrakennetta, jossa kiteytyneenä kuvastuu se, mitä hän on elämänsä aikana oppinut, ajatellut ja tuntenut (Takala 1982, 68). Musiikillinen maailmankuva on yksilön maailmankuvan hierarkkisen järjestelmän osarakenne, hänen musiikkiin liittyvien käsitystensä kokonaisuus. Sen muodostumista, rakennetta ja funktiota koskevat siis samat lainalaisuudet kuin yksilön maailmankuvaa kokonaisuudessaan. Maailmankuvan erilaiset osarakenteet painottuvat eri tavoin 
eri yksilöillä. Musiikillinen maailmankuva heijastaa yksilön yleistä maailmankuvaa, ennen kaikkea tärkeiksi koettuja elämänarvoja, mutta se voi myös olla keskeisimpiä osarakenteita yksilön maailmankuvassa, jolloin musiikkiarvot puolestaan heijastuvat koko elämäntavassa ja arvoissa.

Maailmankuvan muodostumisprosessi on samanlainen kaikilla yksilöillä, sillä pyrkimys hakea informaatiota ja muodostaa sisäinen kuva todellisuudesta on ihmisen lajityypillinen ominaisuus. Ilman tätä kuvaa ihminen ei voi orientoitua ympäristössään. Maailmankuvalla on näin oleellinen ihmisen toimintaa säätelevä funktio, sillä se toimii valikoivan tarkkaavaisuuden ja informaation tulkinnan perustana. Sekä ihmisen ulkoinen että sisäinen toiminta suuntautuu sen pohjalta. Maailmankuvan sisältö muodostuu kuitenkin kaikilla yksilöillä erilaiseksi heidän ainutkertaisten kokemustensa kautta. Maailmankuvan sisältö syntyy yksilön ja ympäristön välisessä vuorovaikutuksessa, jossa yksilö tulkitsee saamaansa informaatiota ja antaa sille merkityksiä. (Rauste-von Wright 1982, 77; Rauste-von Wright, Niemi ja Nurmi 1984, 2-3.) Maailmankuvan keskeisenä rakennusaineena on siis tieto, mutta maailmankuva sisältää nimenomaan tulkittua tietoa todellisuudesta.

Samalla kun ihmiselle kehittyy tiedollisia käsityksiä todellisuudesta, hänelle kehittyy myös tavoitteita suhteessaan ulkomaailmaan mm. toiminnasta saadun palautteen vaikutuksesta. Tästä tavoitellusta suhteesta ulkomaailmaan muodostuu ihmisen motivaatiorakenne eli hänen arvojensa ja tavoitteidensa hierarkia, jonka pohjalta ihminen suuntaa toimintansa. Edelleen maailmankuvaan kuuluu tunteenomaisia aineksia, sillä elämyksellinen sävy liittyy kaikkiin ihmisen toimintoihin. Ihmiselle muodostuu erilaisia asioita koskevia odotuksia ja tunnesuhtautumisia, jotka saattavat olla hyvin pysyviä. (Rauste-von Wright 1982, 77-78; Rauste-von Wright ym. 1984, 3-4.)

Maailmankuvassa voidaan erottaa toisaalta arkielämän kokemusten pohjalta rakentuvat spontaanit käsitykset sekä lähinnä koulutuksen kautta välittyvät ei-spontaanit käsitykset. Maailmankuvan muodostumiseen vaikuttavat koulutuksen ohella luonnollisesti kaikki sosiaaliset vuorovaikutussuhteet ja yhteiskunnassa välittyvä informaatio, etenkin massakommunikaatio. (von Wright 1982, 2; Rauste-von Wright ym. 1984,5 .) Myös musiikillisen maailmankuvan muodostumisen edellytyksenä on, että yksilö oppii tiettyjä peruskäsityksiä musiikista, mm. siitä, mikä on musiikkia ja mikä ei, miten eri musiikinlajit eroavat toisistaan jne (Koskoff 1982, 353-354). Vasta kun yksilöllä on riittävästi tietoa musiikista ja musiikkitapahtumien sisältämästä logiikasta, pystyy hän 
vastaanottamaan ja ymmärtämään musiikin sisältämiä merkityksiä (Leisiö 1981, 245). Peruskäsitykset ovat yhteisiä tietyn kulttuurin jäsenille, ja ne yhtenäistävät yhteisön suhdetta musiikkiin. Niiden ohella yksilö kuitenkin muodostaa ainutkertaisten elämystensä kautta omia, spontaaneja ja yksilöllisiä käsityksiään musiikista. (Koskoff 1982, 353354.) Näin ollen yksilön musiikillinen maailmankuva ei koskaan ole pelkästään yhteisön musiikillisen maailmankuvan eli yhteisöllisten musiikkikäsitysten tuote ja heijastuma (vrt. Kurkela 1986a, 16; Pekkilä 1983, 155).

Kognitiivisen psykologian maailmankuvateorian perustalta musiikillinen maailmankuva määrittyy siis yksilön maailmankuvan hierarkkisen järjestelmän osarakenteeksi, musiikkiin liittyvistä tiedollisista käsityksistä, arvoista ja tunne-elämyksistä muodostuvaksi kokonaisuudeksi, joka ohjaa yksilön musiikillista ajattelua ja musiikkiharrastusta. Sen avulla yksilö jäsentää ja arvottaa eri kanavien kautta välittyvää musiikillista informaatiota ja hahmottaa musiikillista avaruutta, soivan musiikin maailmaa. Tästä lähestymistavasta seuraa, ettei musiikillista maailmankuvaa voida tutkia tai ymmärtää yksinomaan tiedollisten tai opittujen käsitysten järjestelmänä tai yksinomaan subjektiivisena arvojärjestelmänä (vrt. Pekkilä 1988, 63-64), vaan se on kolmesta ulottuvuudesta, kognitiosta, motivaatiosta ja emootiosta muodostuva kokonaisuus, joka sisältää sekä yksilöllistä että yhteisöllistä, kulttuurin jäsenille yhteistä ainesta. Yksilön musiikillisessa maailmankuvassa tiedot, arvot ja elämykset nivoutuvat saumattomasti toisiinsa (ks. von Wright 1982 , 1), eikä niitä sen vuoksi voida tutkia erillään toisistaan. Sen sijaan samoja asioita koskevat ei-spontaanit käsitykset ja omakohtaisten elämysten kautta muodostuneet spontaanit käsitykset saattavat jäädä rinnakkaisiksi ja toisistaan irrallisiksi (Rauste-von Wright 1982, 77-78). Musiikkikäsitysten kohdalla näyttää usein olevan näin: yksilö tietää, minkälainen musiikki on "arvokasta", mutta arvostaa itse aivan muunlaista musiikkia.

\section{Tutkimusmetodi}

Kuten Maijaliisa Rauste-von Wright $(1979,24)$ on todennut, kovien menetelmien käyttömahdollisuudet ovat varsin rajoitetut silloin kun tutkimuksen kohteena ovat yksilöiden käsitysjärjestelmät ja ne merkitykset, joita he erilaisille asioille ja ilmiöille antavat. Kovia menetelmiä, esimerkiksi strukturoitua kyselyä, käytettäessä ilmiöiden jäsennys ja 
luokittelu tapahtuu jo etukäteen tutkijan toimesta, jolloin tutkimuksen validiteetti riippuu tutkijan ja tutkittavien käsitejärjestelmien vastaavuudesta, kun taas ns. pehmeillä menetelmillä saadaan tietoa tutkittavien omasta tavasta jäsentää ja luokittaa asioita (emt, 24). Musiikkikirjastonhoitajien musiikillista maailmankuvaa koskevassa tutkimuksessa sekä aineiston keruu- että analyysimenetelmä oli kvalitatiivinen. Aineisto kerättiin ns. teemahaastattelumenetelmällä, jolloin haastattelun aihepiirit eli teema-alueet oli suunniteltu etukäteen, mutta ei kysymysten tarkkaa muotoa tai järjestystä (ks. Hirsjärvi ja Hurme 1982). Keskeisiä teemaalueita olivat musiikkikirjastonhoitajien käsitykset musiikkikirjaston tehtävistä sekä musiikkiäänitteiden valinnassa noudatettavista periaatteista. Laadullinen maailmankuvatutkimus on niin työlästä ja paljon tutkimusaineistoa tuottavaa, että tutkittavien määrä on pakko rajata pieneksi. Tutkimuksen kohderyhmänä olivat kaikki musiikkikirjastonhoitajat yhden läänin alueelta ja haastateltavia oli yhteensä 15 . Haastateltavat suhtautuivat tutkimukseen myönteisesti ja monet kokivat tilaisuuden työnsä perusteiden pohtimiseen ja käsitystensä jäsentämiseen keskustelun avulla mielekkääksi ja hyödylliseksi.

Laadullisessa analyysissä pyritään tutkittavien ajatusstruktuurien ja arvorakenteiden hahmottamiseen ja tässä, samoin kuin aineiston keruussa, on tärkein tutkimusväline tutkija itse. Dialoginen asetelma tutkijan ja tutkittavien välillä säilyy myös analyysissä: tutkija peilaa tutkittavien maailmankuvaa oman maailmankuvansa ja omaksumansa taustateorian avulla, ja tätä kautta tulee näkyville asioita ja merkityksiä, jotka kaipaavat lähempää analyysiä. Analyysin "polttopisteitä" löytyy myös tutkittavien ajattelun keskinäisistä eroista. Kvalitatiivinen analyysihän pohjautuu ajatteluun, jonka mukaan yksittäistapauksesta voi löytyä jotain kohteelle olennaisesti tyypillistä. Analyysissä ei kuitenkaan etsitä pelkästään "tyypillistä toimintaa" tai "keskimääräisiä henkilöitä" vaan hyödynnetään myös epätavallista, yllättävää ja ei-tyypillistä (Grönfors 1982, 148). Tulokset ovat laadullisessa tutkimuksessa usein teoreettisen idean koettelemista, eikä tulosten yleistettävyys määräydy pelkästään empiirisestä tasosta vaan ennemminkin esitetyn teorian pätevyydestä (Alasuutari 1984, 326).

Kulttuurinsisäisten eroavuuksien painottaminen johtaa luonnollisesti siihen, että tutkijan oma tausta ja näkemykset tulevat huomion kohteiksi. Tämän toteamuksen ei kuitenkaan tarvitse johtaa arvojen ja käsitysten relativismiin, jonka mukaan tutkijan ja haastateltavien katsomukset olisivat molemmat yhtä epäluotettavia ja todellisuutta vääristeleviä. Analyysissä on kysymys ajatuksen ja kokemuksen keskinäisen vuorovaiku- 
tuksen kautta syntyneiden maailmankuvien kohtaamisesta, jonka tuloksena syntyvään tietoon sekä tutkija että tutkimuksen kohde antavat panoksensa. (ks. Puhakka 1977, 69.)

\section{Musiikkikirjastonhoitajien käsitykset musiikista ilmiönä}

Musiikkikirjastonhoitajien musiikillista maailmankuvaa olennaisimmin muotoava piirre on käsitys siitä, minkälainen käytäntö musiikki on eli minkälaista musiikki on luonteeltaan. Se on perusolettamus, joka vaikuttaa kaikkiin muihin musiikkiin liittyviin käsityksiin ja heijastuu niissä. Tämä käsitys ei koske ainoastaan musiikin aluetta, yhtä hyvin voitaisiin puhua taidekäsityksestä tai kulttuurikäsityksestä. Käsitykseen musiikin luonteesta liittyvät erottamattomasti käsitykset musiikkiarvojen perustasta ja musiikinlajien välisestä suhteesta.

Haastateltavat jakautuivat musiikkikäsityksensä perusteella kolmeen ryhmään. Nämä musiikillisen maailmankuvan "tyypit" olen nimennyt niiden keskeisten piirteiden pohjalta hierarkiseksi, autonomiseksi ja kulttuuriseksi musiikkikäsitykseksi. Haastateltavien enemmistöllä (13/15) oli autonominen käsitys musiikista. Hierarkista ja kulttuurista musiikkikäsitystä edusti kumpaakin vain yksi haastateltava. Tärkein musiikilliseen maailmankuvaan vaikuttava tekijä näyttää olevan ikä (ks. myös Leisiö 1981, 240-241). Erot haastateltavien käsityksissä ovat parhaiten ymmärrettävissä sukupolvieroina siitä huolimatta, että jakauma ei aivan täysin vastaakaan haastateltavien ikäjakaumaa. ${ }^{2}$ Hierarkkista musiikkikäsitystä edustava haastateltava kuuluu vanhimpaan ikäpolveen haastateltavien joukossa, kulttuurista musiikkikäsitystä edustava nuorimpaan. Keskipolven (1950-luvulla syntyneiden) edustajat ovat omaksuneet autonomisen käsityksen musiikista, samoin kaksi vanhimman ikäpolven edustajaa.

Musiikkikirjastotoiminnan kannalta tarkasteltuna musiikkikäsitykset ovat niitä perusolettamuksia, joiden varaan koko toimintapoliittinen linja

2) Haastateltujen ikärakenne

$\begin{array}{lr}\text { Ikäryhmä } & \text { n } \\ 20-29 & 1 \\ 30-39 & 11 \\ 40-49 & 3\end{array}$


rakentuu. Musiikkikirjastotoiminnan alkuvaiheessa maassamme noudatettiin Seppo Nummen hahmottelemaa toimintapolitiikkaa, joka perustui selkeän hierarkiseen käsitykseen musiikista. 1970-luvulta lähtien tavoitteita ryhdyttiin muotoilemaan uudestaan autonomisen musiikkikäsityksen suuntaisesti. Tähän vaikutti ennen kaikkea se, että vaikka virallista taidepolitiikkaa edelleen saatettiin harjoittaa hierarkisen musiikkikäsityksen pohjalta, musiikkikulttuurimme ja ihmisten enemmistön musiikkikäsitykset olivat afroamerikkalaisen populaarikulttuurin vakiintumisen myötä muuttuneet perusteellisesti - "taidetta" ymmärrettiin löytyvän muualtakin kuin länsimaisen klassisen konserttimusiikin piiristä. Julkisen musiikkikirjastopoliittisen linjan taustalla on edelleenkin autonominen käsitys musiikista (ks. Musiikkikirjastotoiminnan käsikirja 1986, 29-31).

On selvää, etteivät haastateltavien ajattelusta löydetyt kolme tapaa ymmärtää musiikkia ilmiönä ole ominaisia yksinomaan tutkittavalle ryhmälle vaan ne kuvastavat yleisemminkin yhteiskunnassamme, eri aikoina ja musiikkitieteen eri alueilla vallitsevia musiikkikäsityksiä. Tämän vuoksi niitä perusolettamuksia, joiden varaan haastateltavien musiikillinen maailmankuva on rakentunut ja joita he musiikkikirjastotyössä portinvartijoina toimiessaan noudattavat, on tarpeellista tarkastella myös kriittisesti.

\section{Hierarkkinen musiikkikäsitys}

Hierarkkista musiikkikäsitystä kuvastavat näkemykset, joiden mukaan musiikkikirjaston ensisijaisena tehtävänä on edistää länsimaisen klassisen konserttimusiikin harrastusta, että klassista musiikkia tulee kokoelmaan valittavien äänitteiden jakaumasta olla yli $50 \%$, ja että iskelmämusiikkia ei tulisi hankkia musiikkikirjaston kokoelmaan lainkaan.

Hierarkkinen musiikkikäsitys pohjautuu korkeakulttuuriseen näkemykseen musiikista. Musiikki ymmärretään taiteenlajiksi, jonka päämäärät ovat yksinomaan taiteellis-esteettisiä ja joka siten on arvoiltaan ja funktioiltaan autonominen (Willis 1984, 138). Erityisesti länsimaiselle konserttimusiikkitraditiolle ominainen, musiikin tuottajien ja vastaanottajien erillisyytenä ilmenevä relatiivinen autonomisuus yleistetään tällöin koskemaan kaikkia musiikillisia käytäntöjä (Bradley 1980, 49). Musiikkiarvojen perustan käsitetään olevan musiikissa itsessään, niiden ymmärretään sisältyvän musiikin rakenteisiin ja ominaisuuksiin. 
Hierarkkiselle musiikkikäsitykselle on ominaista musiikillisen arvomaailman tiukka sitoutuminen yhteen tiettyyn musiikilliseen traditioon, yleensä länsimaiseen klassiseen konserttimusiikkiin. Tämän tradition sisällä syntyneitä arvokriteereitä ja esteettis-sävellysteknisiä normeja sovelletaan kaikkeen musiikkiin, niiden katsotaan olevan universaaleja ja objektiivisia (Shepherd 1982, 147-148). Näin syntyy käsitys musiikinlajien välillä vallitsevasta hierarkisesta arvojärjestyksestä. Musiikin nähdään jakautuvan "vakavaan" taidemusiikkiin ja "kevyeen" populaarimusiikkiin, jotka eroavat toisistaan laadultaan, funktioiltaan ja vastaanottotavoiltaan. Hierarkkisen musiikkikäsityksen mukaan musiikkiarvot ovat absoluuttisia, musiikin arvon katsotaan pysyvästi ja epäilyksettömästi määräytyvän tiettyjen esteettisten arviointikriteerien perusteella.

Musiikinlajien arvottavan erottelun perusteluna esitetään useimmiten, että populaarimusiikin luonnetta säätelevät kaupalliset ja ulkomusiikilliset funktiot kun taas taidemusiikki on "taidetta taiteen vuoksi". Populaarimusiikki pyrkii viihdyttämään ja on sen seurauksena luonteeltaan steoreotyyppistä ja helposti vastaanotettavaa kun taas taidemusiikki on tietoisuutta avartavaa ja se on vastaanotettava "esteettisessä kontemplaatiossa". (ks. Heiniö mt. 191-196.) Kvalitatiivinen erottelu perustuu myös näkemykseen musiikinlajien vertailukelpoisuudesta. Populaarimusiikin katsotaan kaikista uusista piirteistään huolimatta hyödyntävän (triviaalisti) taidemusiikin piirissä kehittyneitä keinovaroja, pitäytyvän funktionaaliseen tonaalisuuteen (ks. Heiniö mt. 190-191). Näin populaarimusiikkia on analysoitu perinteisillä musiikkitieteen menetelmillä, jotka ovat olemukseltaan formalistisia eli ne keskittyvät tarkastelemaan esimerkiksi muotoa ja temaattista kehittelyä, jotka ovat keskeisiä elementtejä notaatioon perustuvassa länsimaisessa taidemusiikissa (Tagg 1982, 41-42). Tällä tavoin on päädytty esimerkiksi seuraavanlaisiin johtopäätöksiin: "Populaarimusiikissa "ikuiset arvot" ovat kappaleesta toiseen toistuvissa formeleissa, taidemusiikissa ne taas konkretisoituvat yksittäisissä, kauan elävissä ja siten musiikinhistoriallista tietoisuutta muokkaavissa teoksissa" (Heiniö 1987, 195). Elementit, jotka ovat keskeisiä taidemusiikissa ja sen analyysissä, eivät kuitenkaan ole keskeisiä populaarimusiikissa. Afroamerikkalainen populaarimusiikki ei perustu rakenteelliselle kehittelylle, se ei ole luonteeltaan ekstensionaalista vaan intensionaalista. Perinteiset musiikkitieteelliset analyysi- ja arviointimenetelmät eivät tavoita niitä aspekteja, jotka afrikkalaisesta kuulonvaraisesta musiikkiperinteestä kehittyneessä afroamerikkalaisessa populaarimusiikissa ovat keskeisiä: soundi, esitystapa, improvisaatio ja rytmi. (Virden \& Wishart 1977, 162-163; Vulliamy 1977, 183.) 


\section{Autonominen musiikkikäsitys}

Useimmat haastateltavat asettivat musiikkikirjaston tehtäväksi monipuolisen kokoelman tarjoamisen. Kokoelmaan valittavan musiikin tulisi olla laadukasta ja arvoltaan kestävää. Haastateltavat katsoivat, että valinnassa tulee noudattaa musiikinlajien keskinäisen arvottamattomuuden periaatetta, jonka mukaan musiikinlajit ymmärretään keskinäisesti tasaarvoisiksi ja kutakin musiikinlajia arvotetaan sille ominaisten sisäisten arviointikriteerien perusteella. Mitään musiikinlajia ei useimpien haastateltavien mielestä ole syytä sulkea kokonaan kokoelman ulkopuolelle, mutta kotimaiseen iskelmämusiikkiin ja ylikansalliseen "hittimusiikkiin" ja erityisesti diskomusiikkiin suhtauduttiin kriittisemmin kuin muihin musiikinlajeihin. Niiden katsottiin sisältävän etupäässä yksinomaan kaupallisin näkökohdin tehtyä, nopeasti ohimenevää ja musiikillisesti vähäarvoista aineistoa, jota ei ole syytä hankkia musiikkikirjastoon suuresta kysynnästä huolimatta. Haastateltavat näkivät kysynnän kohdistuvan yksipuolisesti aineistoon, joka ei täytä musiikkikirjaston valintakriteereitä. Asiakkaiden hankintatoivomukset toteutetaan mikäli ne täyttävät hankintakriteerit, mutta haastateltavien ajattelussa kysyntä on useimmiten ristiriidassa laatukriteerin kanssa. Haastateltavat kertoivat luottavansa musiikin arvottamisessa lehtien musiikkiarvosteluihin ja tekevänsä valintapäätökset niiden perusteella. Lehtien musiikkikriitikoiden katsottiin olevan asiantuntijoita omalla alallaan ja arvostelujen katsottiin tarjoavan luotettavan perustan valintapäätöksille.

Näiden näkemysten voidaan katsoa pohjautuvan autonomiseen käsitykseen musiikista. Sekin pohjautuu korkeakulttuuriseen näkemykseen musiikista, eli musiikki ymmärretään arvoiltaan ja funktioiltaan riippumattomaksi taiteenlajiksi. "Musiikillisen" alueen ja musiikin arviointikriteerien nähdään olevan riippumattomia "ulkomusiikillisista" alueista ja arviointikriteereistä. Ero hierarkkiseen musiikkikäsitykseen on siinä, että autonomiseen musiikkikäsitykseen sisältyy näkemys erilaisten esteettisten arvojärjestelmien olemassaolosta ja musiikin eri osa-alueiden autonomisuudesta. Kullakin musiikkityylillä on sen mukaan omat musiikin luomisen sääntönsä ja omat sisäiset arviointikriteerinsä. Musiikinlajeja ei sen vuoksi voida vertailla toisiinsa tai asettaa keskinäiseen arvojärjestykseen. Autonomisen musiikkikäsityksen mukaan musiikkiarvot ovat objektiivisia. Niiden katsotaan määräytyvän musiikin sisäisistä ominaisuuksista käsin kullekin musiikkityylille ominaisten arviointikriteerien perusteella. 
Autonomisen musiikkikäsityksen ytimessä on "laadun" käsite. Käsitteeseen jo sinänsä sisältyy ajatus, että on olemassa objektiivisia perusteita "hyvän" ja "huonon" musiikin erottelemiseksi. Sekä hierarkkisen että autonomisen musiikkikäsityksen lähestymistapa musiikkiin on erotteleva ja arvottava.

Näkemykset laatukriteerin ensisijaisuudesta, laadun ja kysynnän ristiriitaisuudesta sekä luottamus asiantuntijoihin musiikin arvottamisessa perustuvat selkeästi käsitykseen musiikista autonomisena käytäntönä ja musiikkiarvojen objektiivisuudesta. Monipuolisuuden ja musiikinlajien keskinäisen arvottamattomuuden vaatimukset taas kuvastavat näkemystä erilaisten esteettisten arvojärjestelmien olemassaolosta. Haastateltavien ajattelussa on kuitenkin yksi piirre, joka näyttää heijastavan pikemminkin hierarkista kuin autonomista käsitystä musiikista, nimittäin kriittinen suhtautuminen iskelmä- ja ns. listamusiikkiin. Haastateltavat pitivät kyseenalaisena näiden kestävyyttä, kun taas klassisen musiikin, jazzin ja kansanmusiikin musiikillisia arvoja pidettiin itsestäänselvänä. Tämä piirre ei kuitenkaan ole ristiriidassa autonomisen musiikkikäsityksen kanssa vaan sen looginen seuraus. On kuitenkin tarpeellista tutustua toisenlaiseen lähestymistapaan ymmärtääksemme miksi näin on.

\section{Kulttuurinen musiikkikäsitys}

Yksi haastateltavista piti kysyntää yhtenä tärkeänä valintaperiaatteena. Hän ei nähnyt laadun ja kysynnän olevan keskenään ristiriidassa vaan korosti sitä, että ihmisten musiikkiharrastuksen ja asiakkaiden musiikkimaun tulee vaikuttaa valintaan sekä kokoelman jakautumiseen eri musiikinlajien välillä. Hän kertoi myös valitsevansa iskelmämusiikin ensisijaisesti asiakkaiden mielipiteiden perusteella. Suomalaisen musiikkikulttuurin hän näki olevan jakautunut viralliseen, tuettuun musiikkikulttuuriin ja epäviralliseen musiikkikulttuuriin. Hänen mielestään musiikkikirjastojen tulisi erityisesti pyrkiä tukemaan valtion ja kuntien rahoittamien virallisten musiikki-instituutioiden ulkopuolella kukoistavaa musiikkiharrastusta.

Tämä haastateltava oli ainoa, jolla musiikkikirjastotyötä koskevat käsitykset olivat selvästi nivoutuneet käsitykseen suomalaisesta musiikkikulttuurista ja sen rakenteesta. Kulttuurisen musiikkikäsityksen mukaan musiikk -käsitteeseen sisältyy koko musiikkikulttuuri, ei pelkästään soivat tuotteet. Tämän näkemyksen pohjalta onkin johdonmukaista ymmärtää myös musiikkikirjastotyö osana musiikkikulttuuria. 
Kulttuurinen musiikkikäsitys on lähtöisin etnomusikologiasta, ja se on myös modernin musiikkisosiologian perustana. Musiikkitiede on sen sijaan perinteisesti pohjautunut korkeakulttuuriseen, hierarkiseen musiikkikäsitykseen (ks. esim. Brooks 1982, 10-13).

Kulttuurisen musiikkikäsityksen mukaan musiikki ei ole ympäröivästä yhteiskunnasta riippumaton, autonominen taiteenlaji, eikä musiikkia voida ymmärtää pelkästään tiettyjen esteettisten sääntöjen mukaan organisoiduksi ääneksi, säveltaiteeksi. Musiikki on sosiaalinen käytäntö, se on yksilöiden vuorovaikutusta tietyn yhteiskunnan ja kulttuurin puitteissa.

Millään musiikkityylillä ei kulttuurisen musiikkikäsityksen mukaan ole omia "sisäisiä" arviointikriteereitään, sillä ne ovat aina musiikkia tuottavien ja vastaanottavien yksilöiden arviointikriteereitä (Blacking 1973, 25). Musiikkiarvot eivät määräydy musiikista itsestään käsin, sillä ne ovat opittuja tajunnallisia ilmiöitä, jotka ovat ympäröivän todellisuuden heijastumaa (Leisiö 1981, 243). Nykyaikaisissa, teollistuneissa erityneen työnjaon yhteiskunnissa ei vallitse yhtenäistä arvomaailmaa vaan arvot ovat ryhmäkohtaisia. Arvojen välittymisen kannalta tärkeimpiä tekijöitä ovat ikä ja luokka-asema, mutta niihin vaikuttavat myös esimerkiksi sukupuoli, etnisiteetti ja kạnsallisuus. (Middleton 1987, 174.) Musiikkia arvottavat siis omaan aikaansa sidoksissa olevat yksilöt, musiikkiarvot eivät määräydy musiikista itsestään käsin vaan ne ovat subjektiivisia ja ajallisesti muuttuvia.

Erilaisissa kulttuurisissa ja materiaalisissa olosuhteissa elävien ihmisten kokemusmaailmat eroavat toisistaan. Sen vuoksi ei myöskään ole olemassa yhtä universaalia musiikillista kieltä vaan lukemattomia erilaisia musiikkeja ja musiikkityylejä. (Blacking 1981, 10.) Kaikkialla ja kaikkina aikoina musiikki kuitenkin sisältää viestintää (Bengtsson 1973, 8). Kussakin musiikkityylissä on omat musiikin luomisen sääntönsä ja esteettiset norminsa nimenomaan sen vuoksi, että ne viestivät täysin erilaisia asioita (Virden \& Wishart 1977, 163). Eri musiikkityylit viestivät erilaisia arvomaailmoja ja erilaisia käsityksiä todellisuudesta. Sen vuoksi musiikkia ei voida arvottaa ottamatta huomioon niitä merkityksiä eli sisäisiä ilmaisutehtäviä, joita musiikilla on yleisölleen (Shepherd 1977a, 42). Musiikillisten muotojen ja rakenteiden viestimät merkitykset vaihtelevat eri kulttuureissa hyvin voimakkaasti, ja niiden kunnollinen ymmärtäminen edellyttää tuolle kulttuurille ominaisen maailmankuvan ja ajattelutavan ymmärtämistä (Lehtonen 1986, 17; Saunio 1982, 32). Kulttuurisen musiikkikäsityksen mukaan onkin mielekkäämpää pyrkiä ym- 
märtämään musiikin merkityksiä kuin pyrkiä arvottamaan musiikkia (ks. esim. Middleton \& Horn 1981, 2).

Tietyn musiikkityylin tuottajat tai vastaanottajat eivät välttämättä rajaudu johonkin selvästi määrittyvään ikä- tai sosiaaliryhmään, mutta musiikki kuitenkin aina tuottaa ja rakentaa yhteistä identiteettiä vastaanottajilleen. Yksilö valitsee musiikkia, jonka sisältämät viestit kertovat hänen omasta arvo- ja kokemusmaailmastaan, ja näin tehdessään hän identifioituu siihen ihmisryhmään, joka ymmärtää samanlaisia merkityksiä ja (usein hyvinkin tietoisesti) erottautuu niistä ihmisistä, jotka kuuntelevat toisenlaista musiikkia. (Frith 1981, 164; van Elderen 1984, 114.) Musiikin funktio ei koskaan ole "puhtaasti" taiteellis-esteettinen, koska musiikki ei tuota pelkästään esteettisiä elämyksiä, se on aina myös sosiaalisia kokemuksia ja sosiaalisia merkityksiä. Musiikin avulla yksilö paikantaa itsensä ympäröivässä sosiaalisessa kentässä.

Musiikinlajit ovat siis sosiaalisia kategorioita: niitä pitävät yllä ja tekevät merkityksellisiksi tietyt sosiaaliset ryhmät (Willis 1984, 139). Musiikinlajien väliset suhteet kuvastavat näiden ryhmien välisiä suhteita. Teollistuneissa yhteiskunnissa musiikin kenttä on jakautunut kahteen vyöhykkeeseen: eliitin taidemusiikkitraditioon ja "kansan" populaarimusiikkitraditioon, jonka juuret ovat maaseudun kansanmusiikkitraditiossa (Leisiö 1983, 207). Kulttuurisen musiikkikäsityksen mukaan populaari- ja taidemusiikki eivät musiikin kentällä, musiikillisessa julkisuudessa ole tasa-arvoisessa asemassa. Koska musiikki on kommunikaatiota, tapa jäsentää ympäröivää todellisuutta, voidaan tästä toiminnasta, kuten kaikesta kommunikaatiosta, erottaa vallankäytön ulottuvuus eli se alue, jossa säädellään millaisilla ja kenen luomilla ehdoilla musiikkia tuotetaan ja vastaanotetaan sekä miten siitä kirjoitetaan ja puhutaan (Sarjala 1986, 81-82). Musiikillinen julkisuus on musiikkikulttuurin säätelyn aluetta, sillä sen kautta vaikutetaan siihen, miten musiikkia harrastavat ja siitä elantonsa saavat ihmiset määrittävät musiikillisia ilmiöitä (emt, 81-82). Musiikillisessa julkisuudessa populaarimusiikki on "alistettu" vyöhyke, taidemusiikki "hegemoninen" vyöhyke (Middleton 1987, 174). Musiikillisten ilmiöiden määrittely on tapahtunut taidemusiikin arvomaailman kautta ja sen näkökulmaa musiikkiin on pidetty universaalina ja objektiivisena (Shepherd 1977b, 65; Wishart 1977, 235).

Pierre Bourdieun mukaan musiikki ja musiikkimaku ovat kulttuurieliitille - enemmän kuin muille ryhmille - erottautumisen välineitä. Kulttuurieliitti vastustaa liikettä kohti kulttuurista demokratiaa ja pyrkii vakiinnuttamaan omistamansa kulttuurisen pääoman arvon ja legitimi- 
teetin, mistä luonnollisesti seuraa välinpitämätön ja antagonistinen suhtautuminen "massojen" populaarikulttuuriin. (Bourdieu 1985; Roe 1987.) Musiikin kenttä ei siis ole moniarvoinen eikä avoin kaikille musiikillisille ilmiöille ja mielipiteille, kulttuurieliitin intressien mukaista on ollut asettaa sille ennakkomääräyksiä, joiden avulla on (tiedostamattomasti) pyritty vakiinnuttamaan musiikillisen kentän muoto (Middleton 1987, 174). Esimerkki tällaisesta ennakkomääräyksestä on puhe "kevyestä" ja "vakavasta" musiikista. Näiden termien vakiintuminen kieleen ei suinkaan osoita sitä, että ihmisillä keskimäärin olisi käsitys musiikinlajien erilaisista tehtävistä (vrt. Heiniö 1987, 195) vaan pyrkimystä pitää yllä käsitystä taidemusiikkitradition edustajien "erityisestä" musiikillisesta kompetenssista verrattuna populaarimusiikin vastaanottajien "yleiseen" kompetenssiin. Keveys ja vakavuus eivät ole minkään musiikkiteoksen tai -tyylin sisäisiä ominaisuuksia, ne ovat vastaanottajien vaihtelevia tapoja suhtautua musiikkiin (Blacking 1981, 12). Siinä missä toiset hahmottavat tietyn populaarimusiikkiteoksen yksinomaan kevyenä musiikkina, toisille se saattaa tarjota hyvinkin syvällisiä kokemuksia. Populaarimusiikin vastaanottaminen ei todellisuudessa vaadi sen vähäisempiä musiikillisiä kykyjä kuin taidemusiikinkaan vastaanottaminen. Mm. sosiaalisesta asemasta ja kokemuksista riippuu, minkälaista musiikkia yksilö oppii ymmärtämään. (emt, 12-13.)

Musiikkikulttuurissamme vallitsevaan jyrkkään taide/viihde - jakoon viittasi vain kulttuurisen musiikkikäsityksen omaava haastateltava. Muiden haastateltavien ajattelussa ristiriidat vallitsevat kaupallisen ja eikaupallisen musiikin välillä, eivät eliitti- ja populaarimusiikin välillä. Haastateltavat katsoivat kaupallisen populaarimusiikin dominoivan musiikkikulttuuriamme, eivätkä he nähneet populaarimusiikin heikkoa arvostusta ongelmana.

Korkeakulttuurisesta, autonomisen musiikkikäsityksen näkökulmasta on vaikeaa ymmärtää populaarimusiikin merkityksiä. Tämä selittänee haastateltavien enemmistön suhtautumista esimerkiksi kotimaiseen iskelmämusiikkiin. Jos ei oteta huomioon sitä yleisöä, jonka yhteisiä elämänkokemuksia ja tarpeita tuo musiikki pyrkii ilmaisemaan, päädytään helposti siihen johtopäätökseen, että se on kaupallista ja stereotyyppistä.

\section{Musiikillisen maailmankuvan rakenteesta}

Kansannuorison musiikkikasvatusta tutkinut Vesa Kurkela on todennut, että vaikka musiikkivalistuksen arvomaailma on tällä vuosisadalla vaih- 
dellut suuresti, musiikin arvottamisen takana olevan musiikillisen maailmankuvan dualistinen perusrakenne ei ole muuttunut lainkaan. Musiikkivalistuksen arvomaailma on aina tukeutunut kaksijakoisiin käsitteisiin, vastakkain on asetettu toisaalta legitiimi, arvostettava musiikkiharrastus ja nuorisolle vahingollinen "rappiomusiikki". Musiikillisen maailmankuvan muutos on koskenut ainoastaan yksittäisiä musiikinlajeja ja niiden asemaa arvohierarkiassa, sillä musiikkikulttuurin muutosten edessä musiikkikasvatuksen kenttä on joutunut tekemään uudelleenarviointeja, ja monet musiikinlajit ovat hypänneet "antisankaripuolelta" "sankarien" osastoon: 1940-luvulla jazz oli musiikkikasvattajien pahin vihollinen, kun 1950-luvulta lähtien se on ollut arvostettua ja hyväksyttyä musiikkia ja "rappiomusiikin" aseman on perinyt ensin rock'n'roll ja myöhemmin sen uudemmat johdannaiset. (Kurkela 1986b, 64-65.) Samanlaisen johtopäätöksen musiikillisen maailmankuvan dualistisesta perusrakenteesta on tehnyt Timo Leisiö $(1981,239)$ tutkimuksessaan kahden erilaisesta kulttuuriympäristöstä lähtöisin olevan yksilön musiikillisesta maailmankuvasta. Myös Kimmo Lehtonen $(1986,32)$ on todennut, että musiikki-ilmiön arkista tarkastelukulmaa leimaa selvästi tietynlaisten polariteettien olemassaolo.

Musiikillisen maailmankuvan dualistinen perusrakenne on yhteistä myös musiikkikirjastonhoitajatutkimuksen haastateltaville. Haastateltavien ajattelun ydintä ovat tietyt binääriset käsitykset. Ensinnäkin musiikkiaineiston valintaa koskevat käsitykset rakentuivat oleellisesti laadun ja kysynnän vastakkainasettelulle. Haastateltavat näkivät korostamansa "laadukkaan monipuolisuuden" valintapolitiikan vastakohtana kysyntää noudattavan linjan, jonka tuloksena olisi yksipuolinen, kaupalliseen lista- eli hittimusiikkiin painottuva kokoelma. Laadun ja kysynnän vastakkainasettelu taas pohjautuu dualistisiin käsityksiin itse musiikista. Toistensa vastakohdiksi asettuvat kaupallinen ja ei-kaupallinen musiikki eli "taiteellisessa tarkoituksessa tehty" musiikki ja "kaupallisessa tarkoituksessa tehty" musiikki. Yleensäkin laadun käsitteeseen sisältyy näkemys "hyvän" ja "huonon", musiikillisesti arvokkaan ja arvottoman musiikin olemassaolosta. Myös musiikkiharrastusta jäsennettiin dualistisesti: musiikkiharrastajat ovat joko aktiivisia tai passiivisia. Kulttuurista musiikkikäsitystä edustavan haastateltavan ajattelussa vastakkain eivät asettuneet laatu ja kysyntä tai kaupallinen ja ei-kaupallinen musiikki, mutta hänenkin näkemystensä taustalla oli dualistisia käsityksiä. Hän näki musiikkikulttuurin olevan jakautunut viralliseen ja epäviralliseen musiikkikulttuuriin, tuettuun ja ei-tuettuun musiikkiharrastukseen. 
Lehtonen (1986, 32-37) liittää musiikin alueella esiintyvän jyrkän kaksijakoisuuden musiikin asemaan kulttuuristen merkitysten kantajana ja musiikillisessa julkisuudessa vallitseviin kulttuuriristiriitoihin. Alasuutarin $(1984,326)$ mukaan tietyssä yhteiskunnassa erilaiset elämänmuodot ja osakulttuurit ovat "poleemisessa" suhteessa toisiinsa nähden ja erilaiset yhteiskunnassa esiintyvät, arvoja jäsentävät diskurssit ovat sen vuoksi toinen toistensa negaatioita. Itse asiassa pyrkimys jäsentää ilmiöitä selvien perusluokkien ja vastakohtien avulla on yksi ihmisen lajityypillisistä tavoista hahmottaa maailmaa (von Wright 1982, 3). Kuitenkin voidaan todeta, että musiikin kohdalla vastakkainasettelut ovat jyrkempiä ja "distinktiostrategiat" selvempiä kuin muiden ilmiöiden kohdalla (Bourdieu 1985, 138). Tämä puolestaan aiheutuu musiikin ankkuroitumisesta syvälliseen psyykkisen ja sosiaalisen identiteetin rakentumisen perusproblematiikkaan (Bourdieu mt. 138-139; Lehtonen 1986, 33).

\section{Lähteet}

Alasuutari, Pertti

1984 Onko merkitysten tutkiminen uussubjektivismia? Teoksessa Keskustelua laadullisesta sosiaalitutkimuksesta. Toim. Pertti Alasuutari. Tampereen yliopisto, YhteisBengtsson, Ingmar kuntatieteiden tutkimuslaitos, Sarja C 28/1984, s.313-335.

1973 Musikvetenskap. Stockholm: Esselte.

Blacking, John

1973 How musical is man? Seattle and London: University of Washington Press.

1981 Making artistic popular music - the goal of true folk. Popular Music 1. Ed. Richard Middleton \& David Horn. Cambridge: Cambridge University Press, 9-14.

Bourdieu, Pierre

1985 Sosiologian kysymyksiä. Tampere:Vastapaino. Bradley, Dick

1980 The cultural study of music. Stencilled paper from the Centre for Contemporary Cultural Studies, University of Birmingham, no. 61. 
Brooks, William

1982 On being tasteless. Popular Music 2. Ed. Richard Middleton \& David Horn. Cambridge: Cambridge University Press, 9-19.

Frith, Simon

1981 "The magic that can set you free". The ideology of folk and the myth of the rock community. Popular Music 1 .

Ed. Richard Middleton \& David Horn. Cambridge:

Cambridge University Press, 159-168.

Grönfors, Martti

1982 Kvalitatiiviset kenttätyömenetelmät. Porvoo: WSOY Heiniö, Mikko

1987 Taide- ja populaarimusiikki. Teoksessa Etnomusikologian vuosikirja 1987-1988 Toim. Vesa Kurkela \& Erkki

Pekkilä. Helsinki: Suomen etnomusikologinen seura. 187198.

Hirsjärvi, Sirkka \& Hurme, Helena

1982 Teemahaastattelu. Helsinki.Gaudeamus.

Karttunen, Sanna

1990 Musiikkikirjastonhoitajien musiikillinen maailmankuva.

Helsinki: Suomen musiikkikirjastoyhdistys.

Koskoff, Ellen

1982 The music-network. A model for the organization of music concepts. Ethnomusicology 1982: 3, 353-370.

Kurkela, Vesa

1983 Taistojen tiellä soitettiin - ja soiton tahdissa tanssittiin.

Varkautelaiset työväeniltamat ja niiden musiikki työväen osakulttuurin kaudella. Jyväskylä: Työväenmusiikkiinstituutin julkaisuja 2.

1986a Tanhuten valistukseen. Musiikkivalistus ja perinnetyö Suomen Demokraattisessa Nuorisoliitossa. Helsinki: Työväenmusiikki-instituutin julkaisuja 5 .

1986b Musiikillisen kansanvalistuksen arvohistoria: rakenne, muutos ja muuttumattomuus. Teoksessa Suomalainen musiikkikulttuuri: rakenne ja historia. Helsingin yliopisto, Musiikkitieteen laitoksen julkaisuja 5.

Laitinen, Heikki

1982 Talonpoikaismusiikin suuri murros. Teoksessa Musiikkikulttuurin murros teollistumisajan Suomessa. Toim. Riitta 
Lehtonen, Kimmo

Valkeila. Jyväskylän yliopisto, Musiikkitieteen laitoksen julkaisusarja A 1/1982, 117-129.

1986 Musiikillisen kompetenssin teoria musiikillisen merkityksen muodostamisprosessin ja kulttuuris- sosiaalisten merkitysten strukturaalisena selittäjänä. Turun yliopisto, Kasvatustieteiden tiedekunta, Sarja B 22/1986.

Leisiö, Timo

1981 Tyyli, tunne ja yhteiskunta. Näkökulmia suomalaiseen musiikkikulttuuriin. Musiikki 1981: 3-4, 224-249.

1983 Surface and deep structure in music - an expedition into Finnish music culture. Suomen Antropologi 1983: 4, 198-208.

Manninen, Juha

1977 Maailmankuvat maailman ja sen muutoksen heijastajina. Teoksessa Maailmankuvan muutos tutkimuskohteena.

Toim. Matti Kuusi, Risto Alapuro, Matti Klinge.

Helsinki, Otava, 13-48.

Merriam, Alan P.

1964 The anthropology of music. Bloomington: Northwestern University Press.

Middleton, Richard

1987 Musiikillisen merkityksen artikulointi ja "populaarin" sijoittaminen musiikinhistoriaan. Teoksessa Etnomusikologian vuosikirja 1986. Toim. Vesa Kurkela \& Erkki Pekkilä. Helsinki: Suomen etnomusikologinen seura, 171184.

Middleton, Richard \& Horn, David

1981 Preface to Popular Music 1. Ed. Richard Middleton \& David Horn. Cambridge: Cambridge University Press, 12.

Moisala, Pirkko

1988 Musiikkikulttuurin kognitiivinen viitekehys. Teoksessa Etnomusikologian vuosikirja 1987-88. Jyväskylä. Suomen etnomusikologinen seura, 139-152.

Musiikkikirjastotoiminnan käsikirja 1986. Helsinki: Kirjastopalvelu. Pekkilä, Erkki

1983 "Musiikki" ja "kappalevalikoima". Aspects of the ethnotheory of a Finnish folk musician. Suomen Antropologi 1983: 4, 209-217. 
1988 Musiikki tekstinä. Kuulonvaraisen musiikkikulttuurin analyysiteoria ja -metodi. Acta Musicologica Fennica; 17. Jyväskylä: Suomen musiikkitieteellinen seura.

Puhakka, Kerttu

1977 Maailmankuvien tutkimuksesta ja rakentamisesta. Teoksessa Maailmankuvan muutos tutkimuskohteena. Toim. Matti Kuusi, Risto Alapuro, Matti Klinge. Helsinki: Otava, 49-70.

Rauste-von Wright, Maijaliisa

1979 Nuorison ihmis- ja maailmankuva X. Sosialisaatioprosessi ja maailmankuva. Turun yliopisto, psykologian tutkimuksia 36/1979.

1982 Kasvatustapahtuma ja maailmankuvan kognitiivis-emotionaaliset ainekset. Kasvatus 1982: 2, 76-81.

Rauste-von Wright, Maijaliisa, Niemi, Päivi \& Nurmi, Jari-Erik

1984 Arvojen empiirisen tutkimuksen problematiikkaa. Eri menetelmien vertailua. Turun yliopisto, psykologian tutkimuksia 72/1984.

Roe, Keith

1987 Culture, media and the intellectual. A review of the work of Pierre Bourdieu. Forskning om populärkultur. Red. Ulla Karlsson. Göteborg: Nordicom, 7-16.

Sarjala, Jukka

1986 Suuntaviivoja 1930-luvun Suomen säveltaidetta ympäröivän aatteellisen ilmapiirin tarkastelulle. Teoksessa Suomalainen musiikkikulttuuri: rakenne ja historia. Helsingin yliopisto, Musiikkitieteen laitoksen julkaisuja 5, 75-84.

Saunio, Ilpo

1982 Mitä on etnomusikologia? Teoksessa Musiikki ja yhteisö. Toim. Airi Mäki-Kulmala. Tampereen yliopisto, Yhteiskuntatieteiden tutkimuslaitos, Sarja B 34/1982.

Shepherd, John

1977a Media, social process and music. Shepherd et al. Whose music? A sociology of musical lanquages. London: Transaction Books, 7-51.

1977b The "meaning" of music. Shepherd et al. Whose music? A sociology of musical lanquages. London: Transaction Books, 53-68. 
1982 A theoretical model for the sociomusicological analysis of popular musics. Popular Music 2. Ed. Richard Middleton \& David Horn. Cambridge: Cambridge University Press, 145-177.

Tagg, Philip

1982 Analysing popular music. Popular Music 2. Ed.

Richard Middleton \& David Horn. Cambridge:

Cambridge University Press, 37-67.

Takala, Annika

1982 Maailmankuvan muodostumisesta. Kasvatus 1982: 2, 6770.

van Elderen, P.L.

1984 Music and meaning behind the dykes. Popular Music 4. Ed. Richard Middleton \& David Horn. Cambridge: Cambridge University Press, 97-116.

Willis, Paul

1984 Symboli ja käytäntö. Popmusiikin yhteiskunnallisesta merkityksestä. Teoksessa Keskustelua laadullisesta sosiaalitutkimuksesta. Toim. Pertti Alasuutari.

Tampereen yliopisto, Yhteiskuntatieteiden tutkimuslaitos, Sarja C 28/1984, 137-160.

Virden, Phil \& Wishart, Trevor

1977 Some observations on the social stratification of twentieth century music. In Shepherd et al. Whose music? A sociology of musical lanquages. London: Transaction Books, 155-177.

Wishart, Trevor

1977 On radical culture. Shepherd et al. Whose music? A sosiology of musical lanquages. London: Transaction Books, 233-256.

von Wright, Johan

1982 Maailmankuvan muodostumisen problematiikkaa.

Teoksessa Maailmankuvan muodostumisesta. Joensuun

korkeakoulu, Kasvatustieteiden osaston julkaisuja 22/1982, 1-17.

Vulliamy, Graham

1977 Music and the mass culture debate. Shepherd et al. Whose music? A sociology of musical lanquages. London: Transaction Books, 179-200. 